\title{
Seasonal cycles in whole-body proximate composition and energy content of forage fish vary with water depth
}

\author{
Johanna J. Vollenweider • Ron A. Heintz • \\ Lawrence Schaufler $\cdot$ Robert Bradshaw
}

Received: 22 March 2010/Accepted: 19 October 2010/Published online: 21 November 2010

(C) The Author(s) 2010. This article is published with open access at Springerlink.com

\begin{abstract}
Quantifying the nutritional quality of forage fish is integral for understanding upper trophic levels as forage fish are the dominant prey for top predator fish, marine mammals, and sea birds. Many existing reports documenting body composition of forage species are not comparable due to confounding effects. This study systematically assessed the variability in proximate composition and energy content of 16 forage species in southeastern Alaska $(57.2626 \mathrm{~N} /$ $133.7394 \mathrm{~W}$ ) between 2001 and 2004. Variation in energy and lipid contents was related to habitat, epipelagic planktivores varying most, mesopelagics intermediate, and demersal species relatively invariable. Season was the greatest source of variation as a result of short growing seasons at high latitude and energy allocation strategies for reproduction and growth. Among species that varied seasonally, energy and lipid increased over summer and declined during winter. Annual differences in body composition occurred during periods of peak energy content. Sampling recommendations and guidance for bioenergetics models are provided.
\end{abstract}

Communicated by C. Harrod.

Electronic supplementary material The online version of this article (doi:10.1007/s00227-010-1569-3) contains supplementary material, which is available to authorized users.

J. J. Vollenweider $(\bowtie) \cdot$ R. A. Heintz · L. Schaufler .

R. Bradshaw

Alaska Fisheries Science Center,

Ted Stephens Marine Research Institute,

Auke Bay Laboratories, 17109 Point Lena Loop Road,

Juneau, AK 99801, USA

e-mail: Johanna.Vollenweider@noaa.gov

\section{Introduction}

Marine mammal and seabird population declines hypothesized to be linked to nutritional deficiencies have sparked interest in data describing the proximate composition and energy content of marine forage species. In the last 16 years, at least 13 reports describing forage fish species in the northern Gulf of Alaska and Bering Sea have been published (Anthony et al. 2000; Payne et al. 1999; Van Pelt et al. 1997). Comparison of these reports reveals significant variation in their estimates. For example, the estimated energy content (wet mass) of mature Pacific herring (Clupea pallasii) in these reports differs by more than $300 \%$, ranging from 3.43 (Payne et al. 1999) to $10.47 \mathrm{~kJ} \mathrm{~g}^{-1}$ (Bando 2002). These estimates are confounded by year and location, however. Moreover, the tendency to collect samples in temperate months has led to seasonal discrepancies in reported values. Until the sources of variation underlying estimates of body composition are systematically evaluated, comparisons across species, years, seasons, locations, and gender are compromised. Furthermore, understanding the potential nutritional limitations of marine mammals and seabirds predicted by bioenergetics models is dependent on accurate estimates of body composition of their prey.

Known sources of variation in the body composition of marine forage species include temporal, spatial, ontogenetic, and gender effects. Temporal variability in body composition has been attributed to season and year. Seasonal changes arising from annual reproductive cycles have been reported for several species (Kitts et al. 2004; Robards et al. 1999; Paul et al. 1996). In high latitudes, strong seasonal changes are also associated with prey availability (Foy and Paul 1999; Paul et al. 1998) and are likely the greatest source of discrepancies among published values of North Pacific species. Annual differences in body composition have been ascribed 
to fluctuations in food supply ultimately arising from longterm climatic processes (Moss et al. 2009; Shulman et al. 2005). Spatial variation in body composition may result from differences in habitat quality, including prey availability and quality (Ciannelli et al. 2002; Foy and Norcross 1999). In addition, spatial variation may arise in species whose ranges span latitudes, resulting in varying duration and intensity of seasons (Schultz and Conover 1997). Additional sources of variation in body composition include age (Paul et al. 1998), size, and gender (Anthony et al. 2000; Lawson et al. 1998; Paul et al. 1998). These potential sources of variation may confound mean values of body composition measured from opportunistic collections.

Application of erroneous values for body composition can influence the conclusions drawn from bioenergetic models. Body composition data are integral to bioenergetic models, which are at the core of ecosystem-based approaches to fishery management. Applications of bioenergetic models include (1) quantifying food consumption for animals that are difficult to monitor in captivity (large whales) (Leaper and Lavigne 2007), (2) defining habitat quality in relation to fish condition (Jenkins and Keeley 2010), (3) predicting growth and survival under various environmental conditions (Deangelis et al. 1993), (4) describing trophic interactions among fish assemblages, marine mammals, and seabirds (Bradford-Grieve et al. 2003), (5) estimating biomass removals by a class of predators (Witteveen et al. 2006; Winship et al. 2002), and (6) evaluating competition with fisheries (Morissette et al. 2010). A feature common to all these exercises is prediction of the biomass of prey consumed using estimates of prey energy content. If the estimated energy density of important forage species varies by $300 \%$, then subsequent predictions can vary by the same amount. The broad utility of bioenergetic models emphasizes the importance of accurately parameterizing the models, one component being forage fish body composition. Thus, the influence of environment and life history on forage species' energy dynamics must be quantified so that bioenergetic models for marine piscivorous predators are accurate.

The objectives of this study were to (1) quantify variation in the whole-body proximate composition (lipid, protein, moisture) and energy content of marine forage species, (2) identify the factors contributing to the variation, and (3) provide sampling guidelines for researchers based on our findings.

\section{Materials and methods}

Sampling

We systematically sampled 16 forage species at 2 study sites in southeastern Alaska to evaluate the influence of season, year, habitat, location, and size on variations in whole-body proximate composition and energy content. Fish were collected during seasonal trawl and long-line surveys. Trawl surveys were conducted quarterly from May 2001 to March 2004 at 2 study sites in southeastern Alaska, Lynn Canal and Frederick Sound (Fig. 1). Longline surveys were limited to Frederick Sound and occurred in September 2003 and February and May 2004. Fish schools from the trawl surveys were identified and targeted with a 38-kHz Simrad EK60 hydro-acoustics system and subsequently collected using a mid-water rope trawl. Fish from the long-line surveys were collected using 15 sets randomly located over the sampling area during each survey period. Species selected for proximate analysis were among the most abundant species as determined from acoustical biomass estimates and long-line catch per unit effort (Sigler et al. 2009; Womble and Sigler 2006a, b). A second criterion for species selection was their importance as prey for piscivorous fish, marine mammals (Womble and Sigler 2006b), and seabirds. During each sampling period, 10 individuals of each species were targeted, split evenly between gender and spanning the size range of fish present (Table 1). All species were not abundant during each season, however, resulting in some smaller sample sizes and supplemental collections from intermediate time periods (Table 2).

\section{Sample preparation}

Immediately after physical characteristics were measured, fish were either (1) frozen in refrigerated liquid nitrogen

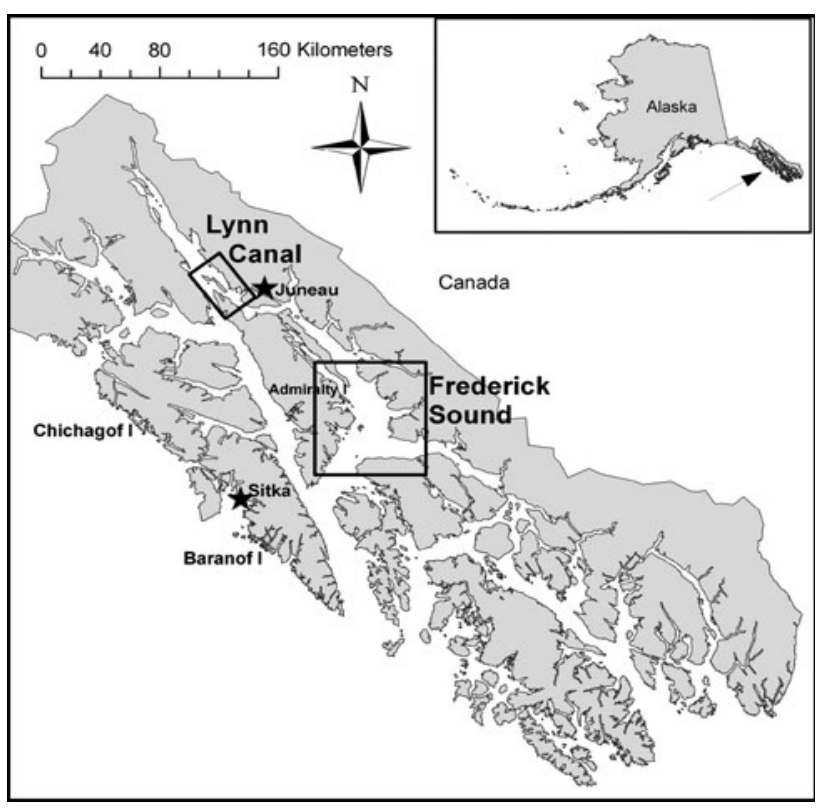

Fig. 1 Map of the two study sites in southeastern Alaska, Lynn Canal and Frederick Sound 
Table 1 Mean size of forage species $( \pm$ sd) examined for body composition organized by habitat

\begin{tabular}{|c|c|c|c|}
\hline & Latin name & Mean length (mm) & Mean mass $(\mathrm{g})$ \\
\hline \multicolumn{4}{|l|}{ Epipelagic } \\
\hline Capelin & Mallotus villosus & 104.7 (19.7) & $7.7(4.2)$ \\
\hline Chinook salmon & Oncorhynchus tshawytscha & $528.4(281.4)$ & $397.0(875.0)$ \\
\hline Pacific herring & Clupea pallasii & $193.4(42.3)$ & $87.5(51.1)$ \\
\hline Pacific sand lance & Ammodytes hexapterus & $120.1(26.2)$ & $8.3(7.5)$ \\
\hline Walleye pollock (juvenile) & Theragra chalcogramma & $248.0(65.3)$ & $139.5(102.2)$ \\
\hline Walleye pollock (YOY) & Theragra chalcogramma & $119.7(24.2)$ & $13.2(8.4)$ \\
\hline \multicolumn{4}{|l|}{ Mesopelagic } \\
\hline California headlightfish & Diaphus theta & $84.2(7.0)$ & $9.6(2.9)$ \\
\hline Commander squid & Berryteuthis magister & $212.3(54.7)$ & $493.1(334.8)$ \\
\hline Eulachon & Thaleichthys pacificus & $164.9(31.3)$ & $31.8(19.1)$ \\
\hline Northern lampfish & Stenobrachius leucopsarus & $98.5(9.7)$ & $11.3(3.4)$ \\
\hline Northern smoothtongue & Leuroglossus schmidti & $117.8(21.8)$ & $12.3(7.4)$ \\
\hline Pacific hake & Merluccius productus & $488.0(66.9)$ & $856.3(419.5)$ \\
\hline Walleye pollock (mature) & Theragra chalcogramma & $473.6(73.3)$ & $897.1(426.5)$ \\
\hline \multicolumn{4}{|l|}{ Demersal } \\
\hline Arrowtooth flounderFlounder & Atheresthes stomias & $607.2(77.7)$ & $2312(956)$ \\
\hline Pacific cod & Gadus macrocephalus & $597.7(80.0)$ & $2418(1,010)$ \\
\hline Pacific halibut & Hippoglossus stenolepis & 746.7 (97.9) & $5151(2,695)$ \\
\hline Sablefish & Anoplopoma fimbria & $615.0(59.9)$ & $2580(893)$ \\
\hline Sandpaper skate & Bathyraja interrupta & $744.5(156.8)$ & $2641(1,858)$ \\
\hline
\end{tabular}

Length is measured as standard length for California headlightfish and northern lampfish, total length for sandpaper skates, mantle length for Commander squid, and the remaining species were measured as fork length. Young-of-the-year is abbreviated as YOY

(when available) $\left(-196^{\circ} \mathrm{C}\right)$ and vacuum sealed, or (2) vacuum sealed and frozen in standard $-20^{\circ} \mathrm{C}$ freezers. Samples were stored preferentially in a $-80^{\circ} \mathrm{C}$ freezer or a $-20^{\circ} \mathrm{C}$ overflow walk-in freezer until chemical analysis, which occurred within 3 months after collection. Whole fish were homogenized while frozen to a puree of uniform color and consistency from which random aliquots were selected for chemical analysis. Stomachs were not excised in order to preserve the condition encountered by their predators.

\section{Energy content}

Whole-body energy content can be measured directly using bomb calorimetry or calculated indirectly as the sum of energy contributed by total-body lipid, protein, and carbohydrate. Fish do not store significant amounts of carbohydrates as energy reserves (Brett 1995); hence, carbohydrates are often considered negligible in fish (Montevecchi and Piatt 1984; Sidwell 1981; Craig et al. 1978). We validated the negligibility of carbohydrates by estimating carbohydrate content as the portion of a fish's mass minus the mass constituted by the directly measured components (water, protein, lipid, ash). On average, carbohydrates constituted $0.03 \%$ of the body composition by mass, which did not significantly influence the total energy content of individual fish (Vollenweider 2005). Energy content was calculated using the energy equivalents of 36.43 and $20.10 \mathrm{~kJ} \mathrm{~g}^{-1}$ (Brett 1995) for lipid and protein, respectively. We confirmed the equality of the direct and indirect methods of measuring energy content using a subset of samples analyzed in a Parr 1425 semi-micro bomb calorimeter. Reported energy equivalents vary considerably, stemming from the degree of saturation of the constituent fatty acids in lipid (Brett 1995; Robbins 1993) and from poor ability to estimate net metabolizable energy from protein (Watt and Merrill 1963). The energy equivalents selected for this study are most appropriate for fish (Brett 1995), which tend to have relatively large quantities of unsaturated fat (Iverson et al. 2002). To address the potential seasonal and ontogenetic changes in degree of fat saturation and metabolically available protein, energy content estimated by both calorimetry and calculation included samples from multiple seasons, species, genders, and sizes. Energy content estimated by calculation and measured by bomb calorimetry was highly correlated $\left(r^{2}=0.94\right)$, and the regression slope was no different than $1(t=0.975, d f=15, \alpha=0.05)$. 
Table 2 Data set used to examine energy content and proximate composition of forage species in southeastern Alaska

\begin{tabular}{|c|c|c|c|c|c|c|c|c|c|c|c|c|c|c|c|c|c|c|}
\hline & \multicolumn{3}{|l|}{2001} & \multicolumn{6}{|l|}{2002} & \multicolumn{5}{|l|}{2003} & \multicolumn{4}{|c|}{2004} \\
\hline & May & Sep & Dec & Mar & Apr & May & Jul & Sep & Dec & Jan & Mar & May & Jul & Sep & Jan & Feb & Mar & May \\
\hline \multicolumn{19}{|l|}{ Epipelagic } \\
\hline Capelin & & & 9 & 20 & 16 & 20 & & 4 & & & 14 & & & 4 & & & & \\
\hline Chinook salmon & & & & & & & & & 3 & & 2 & & 14 & 3 & 10 & & 4 & \\
\hline Pacific herring & 17 & 20 & 20 & 11 & & 21 & 10 & 20 & 31 & 18 & 16 & 36 & & 22 & 24 & & 32 & \\
\hline Pacific sand lance & & & & & & 7 & 10 & & 6 & & 7 & & & & & & & \\
\hline Walleye pollock (Juvenile) & 2 & 20 & 17 & 4 & 8 & 19 & & 18 & 23 & & 40 & & & & & & & \\
\hline Walleye pollock (YOY) & & 10 & 10 & 10 & & 10 & & 10 & 15 & & & & & & & & & \\
\hline \multicolumn{19}{|l|}{ Mesopelagic } \\
\hline California headlightfish & & & & & & & & & & & 1 & 4 & & & 16 & & 11 & \\
\hline Commander squid & & & & & & & & 9 & & & 2 & 11 & & 17 & 25 & & 14 & \\
\hline Eulachon & 9 & 9 & 11 & 20 & & 20 & & 20 & 18 & & 20 & & & & & & & \\
\hline Northern lampfish & & & & & & & & & 27 & & 26 & 30 & & & 26 & & 10 & \\
\hline Northern smoothtongue & & & & & & & & & 14 & & 16 & 17 & & & 29 & & 16 & \\
\hline Pacific hake & 8 & 10 & 10 & 20 & & 12 & & 20 & 25 & & & & & & & & & \\
\hline Walleye Pollock (Mature) & 12 & 38 & 19 & 22 & & 19 & 10 & 20 & 28 & & 13 & & & & & & & \\
\hline \multicolumn{19}{|l|}{ Demersal } \\
\hline Arrowtooth flounder & & & & & & & & 5 & & & & & & 17 & & 17 & & 18 \\
\hline Pacific cod & & & & & & & & & & & & & & 16 & & 17 & & 17 \\
\hline Pacific halibut & & & & & & & & & & & & & & 16 & & 17 & & 16 \\
\hline Sablefish & & & & & & & & & & & & & & 15 & & 17 & & 17 \\
\hline Sandpaper skate & & & & & & & & & & & & & & 17 & & 17 & & 18 \\
\hline Mean monthly SST & 8.9 & 10.0 & 4.0 & 3.8 & 7.4 & 8.7 & 11.7 & 9.7 & 4.6 & 4.3 & 5.1 & 10.6 & 14.2 & 10.9 & 3.7 & 3.6 & 3.9 & 12.5 \\
\hline
\end{tabular}

Numbers reflect the sample size (number of individual fish) in each collection. Young-of-the-year is abbreviated as YOY. Mean monthly sea surface temperatures (SST) $\left({ }^{\circ} \mathrm{C}\right)$ from Wing et al. (2006) are included

Proximate composition

Lipid was extracted from $\sim 0.5 \mathrm{~g}$ of wet sample homogenate using a modification of Folch's method outlined by Christie (2003), in a Dionex Accelerated Solvent Extractor (ASE) 200 with 2:1 (v:v) chloroform:methanol. Extracts were washed successively with a $0.88 \% \mathrm{KCl}$ solution and $1: 1$ (v:v) methanol:deionized water in a volume equal to $25 \%$ of the extract volume to remove coextractables. Excess solvent was evaporated and percent lipid was calculated gravimetrically. Quality assurance (QA) samples included with each batch of 17 samples included a blank to control for cross contamination, a reference material to determine accuracy (high and low lipid references to match samples), and a replicated sample to evaluate precision. Prescribed limits were set for QA sample variation, where replicate samples must not vary by more than 1 standard deviation, reference samples were not to vary by more than $15 \%$, and blanks were not to exceed $0.1 \%$ lipid. If quality assurance samples exceeded these limits, samples were reanalyzed.

Protein content was estimated using a standard method of multiplying total nitrogen content by a conversion factor of 6.25 to account for the nitrogen content of protein (Craig et al. 1978). Nitrogen content was measured with a LECO nitrogen analyzer TruSpec following the Dumas method, in which $\sim 0.1 \mathrm{~g}$ of dried homogenate is combusted at $950^{\circ} \mathrm{C}$ and the expelled nitrogen is measured (Sweeney and Rexroad 1987). All samples were run in duplicate to ensure the coefficients of variation for estimated nitrogen content was less than 1 standard deviation. Mean values of the duplicates were reported. Quality assurance samples included with each batch of 17 samples included a blank reference consisting of cane sugar and a standard reference material (SRM1546) obtained from the National Institute of Standards and Technology. If quality assurance samples exceeded prescribed limits (15\% variation for reference samples, $0.1 \%$ protein for blanks), samples were reanalyzed.

Moisture content was initially measured gravimetrically by drying $\sim 4 \mathrm{~g}$ of the sample homogenate in a $75^{\circ} \mathrm{C}$ oven drying until a constant mass was achieved. Ash content was measured gravimetrically by combusting the dried fish homogenate at $550^{\circ} \mathrm{C}$ for $12 \mathrm{~h}$ in a muffle furnace. After September 2002, a LECO Thermogravimetric Analyzer (TGA) 601 was used to measure moisture and ash content 
gravimetrically using a temperature of $135^{\circ} \mathrm{C}$ for moisture content and $600^{\circ} \mathrm{C}$ for ash content. Moisture and ash values obtained from the 2 methods varied by less than $1 \%$. Moisture analyses were duplicated to ensure the coefficient of variation was less than 1 standard deviation. Mean values of the duplicates were reported. Ash values were not duplicated due to time and sample mass constraints.

Quality of proximate composition values were also evaluated by summing all the components (protein, lipid, moisture, and ash). If sums deviated from $100 \%$ by more than $1.5 \%$, samples were re-run if additional homogenate was available.

\section{Statistical analysis}

Our objective was to determine whether seasonal variation in the energy and proximate composition of forage fish species depends on the habitats they occupy. We began by comparing fish of a given species across seasons by ANOVA to identify the number of adjacent seasons in which energy density and proximate composition varied. All ANOVA assumptions were met. The ANOVAs were one-way tests with season as a fixed factor. A priori contrasts included the comparisons of adjacent seasons with appropriate Bonferroni adjustments made for the total number of contrasts. ANOVA statistics from seasonal comparisons are presented in Table 3. We used the resulting seasonal averages to compute an annualized average and the coefficient of variation for energy density and each of the proximate components. Finally, we performed a one-way ANOVA on the coefficients of variation for each species using habitat as fixed main factor. Each species was categorized as epipelagic, mesopelagic, or demersal based on their average position in the water column observed during the surveys. Three age classes of walleye pollock (Theragra chalcogramma), adult, juvenile, and young-of-the-year (YOY), are treated as different species for the purposes of statistical tests to examine variability within age classes. In all analyses, body composition is expressed on a wet weight basis to preserve the applicability of the values as prey. These data are found in Appendix A. Wet and dry mass computations showed similar trends, except where noted in the results.

The ubiquity of some species allowed us to examine year, location, size, and gender as other potential sources of variation in the estimates of energy density and proximate composition. No interannual comparisons could be made with demersal species that were only collected in 1 year. A priori one-way ANOVA tests were used to compare similar periods across years, locations, and genders. The overall Type I error rate for each species' comparisons was maintained at 0.05 by making the appropriate Bonferroni adjustments to the critical value. Relationships between size and body composition were explored using regression.
Table 3 ANOVA statistics for seasonal comparisons

\begin{tabular}{|c|c|c|c|c|c|c|}
\hline & \multicolumn{3}{|c|}{ Energy content } & \multicolumn{3}{|c|}{ Lipid content } \\
\hline & $d f$ & $F$ & $P$ & $d f$ & $F$ & $P$ \\
\hline \multicolumn{7}{|l|}{ Epipelagic } \\
\hline Capelin & 6,80 & 32.06 & $<0.001$ & 6,80 & 39.20 & $<0.001$ \\
\hline Chinook salmon & 4,14 & 3.38 & 0.039 & 4,14 & 1.57 & 0.238 \\
\hline Pacific herring & 14,252 & 24.44 & $<0.001$ & 14,269 & 17.35 & $<0.001$ \\
\hline Pacific sand lance & 3,26 & 54.78 & $<0.001$ & 3,26 & 35.47 & $<0.001$ \\
\hline $\begin{array}{l}\text { Walleye pollock } \\
\text { (juvenile) }\end{array}$ & 7,146 & 11.47 & $<0.001$ & 7,145 & 10.46 & $<0.001$ \\
\hline $\begin{array}{l}\text { Walleye pollock } \\
\text { (YOY) }\end{array}$ & 5,59 & 8.68 & $<0.001$ & 5,59 & 8.66 & $<0.001$ \\
\hline \multicolumn{7}{|l|}{ Mesopelagic } \\
\hline $\begin{array}{l}\text { California } \\
\text { headlightfish }\end{array}$ & 3,27 & 1.27 & 0.306 & 3,28 & 1.50 & 0.235 \\
\hline Commander squid & 5,70 & 9.75 & $<0.001$ & 5,71 & 9.32 & $<0.001$ \\
\hline Eulachon & 7,118 & 2.22 & 0.037 & 7,118 & 1.76 & 0.101 \\
\hline Northern lampfish & 4,114 & 6.46 & $<0.001$ & 4,114 & 4.96 & 0.001 \\
\hline $\begin{array}{l}\text { Northern } \\
\text { smoothtongue }\end{array}$ & 4,86 & 2.90 & 0.027 & 4,87 & 2.01 & 0.101 \\
\hline Pacific hake & 6,98 & 7.03 & $<0.001$ & 6,98 & 22.55 & $<0.001$ \\
\hline $\begin{array}{l}\text { Walleye pollock } \\
\text { (mature) }\end{array}$ & 8,171 & 11.82 & $<0.001$ & 8,171 & 21.00 & $<0.001$ \\
\hline \multicolumn{7}{|l|}{ Demersal } \\
\hline Arrowtooth flounder & 3,49 & 1.41 & 0.250 & 3,49 & 0.73 & 0.537 \\
\hline Pacific cod & 2,47 & 6.41 & 0.003 & 2,47 & 10.45 & $<0.001$ \\
\hline Pacific halibut & 2,45 & 1.52 & 0.229 & 2,45 & 1.33 & 0.274 \\
\hline Sablefish & 2,43 & 0.77 & 0.468 & 2,43 & 0.76 & 0.472 \\
\hline Sandpaper skate & 2,48 & 0.97 & 0.387 & 2,48 & 4.98 & 0.011 \\
\hline
\end{tabular}

Statistics include degrees of freedom $(d f)$ (between group, within group), $F$ statistic, and $P$ value. ANOVAs were one-way tests with season as a fixed factor. A priori contrasts included comparisons of adjacent seasons with appropriate Bonferroni adjustments made for the total number of contrasts. Young-of-the-year is abbreviated as YOY

\section{Results}

Variations in body composition

Pooled over all collections, the body composition of some species was highly variable, while others were relatively consistent (Fig. 2). Energy content was most variable in Pacific herring, ranging from 3.48 to $12.75 \mathrm{~kJ} \mathrm{~g}^{-1}$ among individual fish. In contrast, Pacific cod (Gadus macrocephalus) were the least variable, ranging from 2.73 to $4.52 \mathrm{~kJ} \mathrm{~g}^{-1}$. Fluctuations in energy content were driven by changes in lipid content $\left(r^{2}=0.96\right)$, which varied more than any other measured component. Consequently, variation in lipid content was most extreme in Pacific herring $(1.1-25.9 \%)$ and minimal in Pacific cod (0.1-4.2\%). Moisture content also varied significantly in some species, 

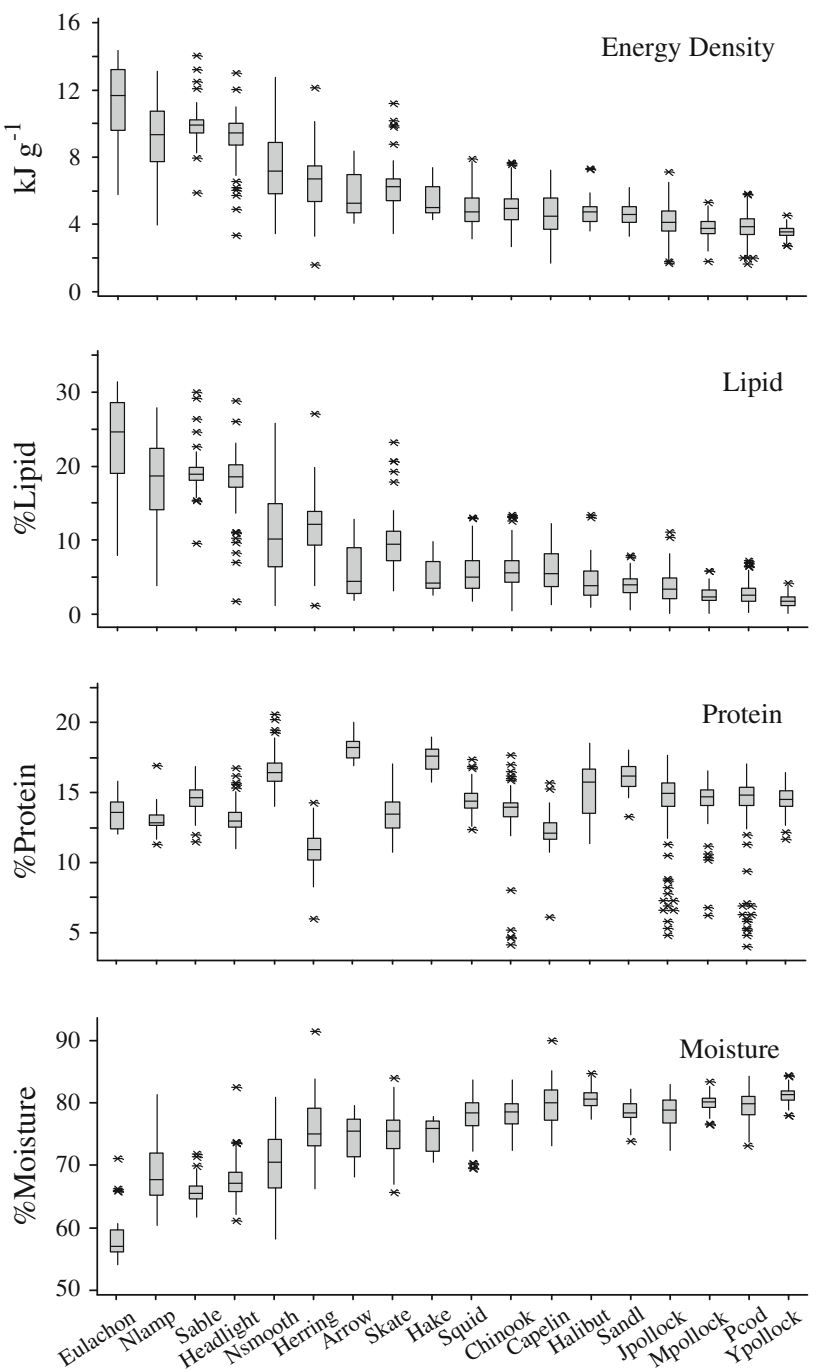

Fig. 2 Boxplots depicting the variation in the body composition of forage species pooled over all collections, including energy density $\left(\mathrm{kJ} \mathrm{g}^{-1}\right), \%$ lipid, \% protein, and \% moisture

as lipid and moisture contents were inversely correlated $\left(r^{2}=0.84\right)$. Accordingly, Pacific herring and Pacific cod were again the species with the maximum and minimum variation (58.18-80.80\% and 77.88-84.33\% moisture, respectively). Protein content was less variable, varying by as much as $10.50-17.70 \%$ in mature walleye pollock and as little as $16.94-20.05 \%$ in chinook salmon (Oncorhynchus tshawytscha).

Seasonal cycles in body composition

Much of the intra-specific variability in body composition was attributed to seasonal changes. Seasonal cycling of body composition was relatively consistent among species. With the exception of chinook and Pacific sand lance (Ammodytes hexapterus), energy content generally increased over summer, peaked in autumn or winter, and
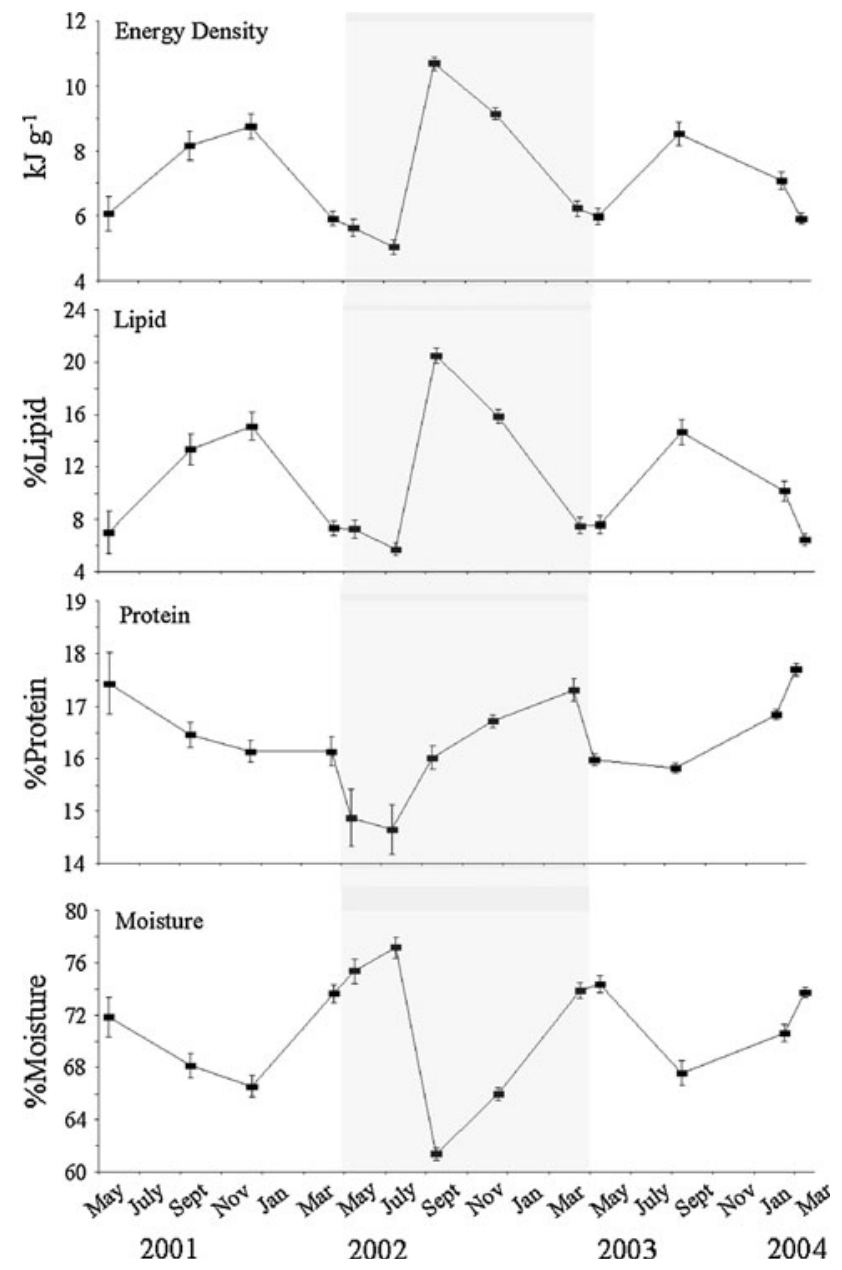

Fig. 3 Seasonal cycles in the body composition of Pacific herring (Clupea pallasi) $( \pm \mathrm{SE})$ is presented as an example of the seasonal cycles observed in other forage fish

declined to a minimum in spring or early summer (Fig. 3 depicts the seasonal cycle of herring body composition as an example). (Chinook and Pacific sand lance cycled in an opposite manner.) Seasonal flux in lipid content mirrored patterns in energy content; however, the magnitude of changes in lipid was more dramatic. Moisture cycled in a manner opposite to lipid. Slight asynchrony in the timing of the seasonal cycles resulted in varying ranks of species such that no one species was consistently the best or worst source of energy or lipid. Unlike energy and lipid contents, protein content had no distinct seasonal cycling pattern consistent among species. The only seasonal trend detected for protein content was that there was a tendency for protein content to decline twice as frequently in March and May than in September and December.

Seasonal cycles and habitat

Seasonal cycles in body composition were most prominent in surface-oriented species and became less frequent as water 
depth increased. Seasonal differences in energy content were detected in all epipelagic species (ANOVA, $P<0.039$ ), $86 \%$ of mesopelagic species (ANOVA, $P<0.037$ ), and $20 \%$ of demersal species (ANOVA, $P=0.003$ ) (Table 3 ). Significant changes in energy content between successive sampling periods occurred $52 \%$ of the time for epipelagic species, $20 \%$ for mesopelagic species, and $10 \%$ for demersal species (Fig. 4). The magnitude of seasonal changes also declined with depth. The coefficient of variation (CV) of the mean annual energy density of epipelagic species (17.4) was more than twice that of demersal species (6.1), with mesopelagic species intermediate (9.8) (ANOVA, $F(2,15)=$ 4.36, $P=0.032$ ) (Fig. 5).

Variation in energy content was a consequence of variation in lipid and, to a lesser-degree, protein contents. As with energy, seasonal changes in lipid content were detected in more near-surface species, occurred more frequently over the course of a year, and were greater in magnitude. Lipid varied seasonally in $83 \%$ of epipelagic species (ANOVA, $P<0.001$ ), 57\% of mesopelagic species (ANOVA, $P<0.002$ ), and $40 \%$ of demersal species (ANOVA, $P<0.011$ ) (Table 3). Seasonal differences in lipid content between successive sampling periods occurred at the same frequency as in energy content $(52,20$, and $10 \%$ for epipelagic, mesopelagic, and demersal species, respectively) (Fig. 4). CV's of the mean annual lipid content were twice as great in epipelagic species (42.0) as in mesopelagic (18.6) and demersal species (19.0) (ANOVA, $F(2,15)=$ 4.28, $P=0.034$ ) (Fig. 5). Seasonal flux in moisture content mirrored those patterns described for energy and lipid contents (Figs. 4, 5).
Fig. 4 Frequency of seasonal variation in body composition of forage species by depth group expressed as the percentage of comparisons of adjacent seasons that are statistically different $( \pm \mathrm{SE})$. Like symbols indicate statistically similar groups determined by ANOVA $(P<0.05)$
Wet Mass
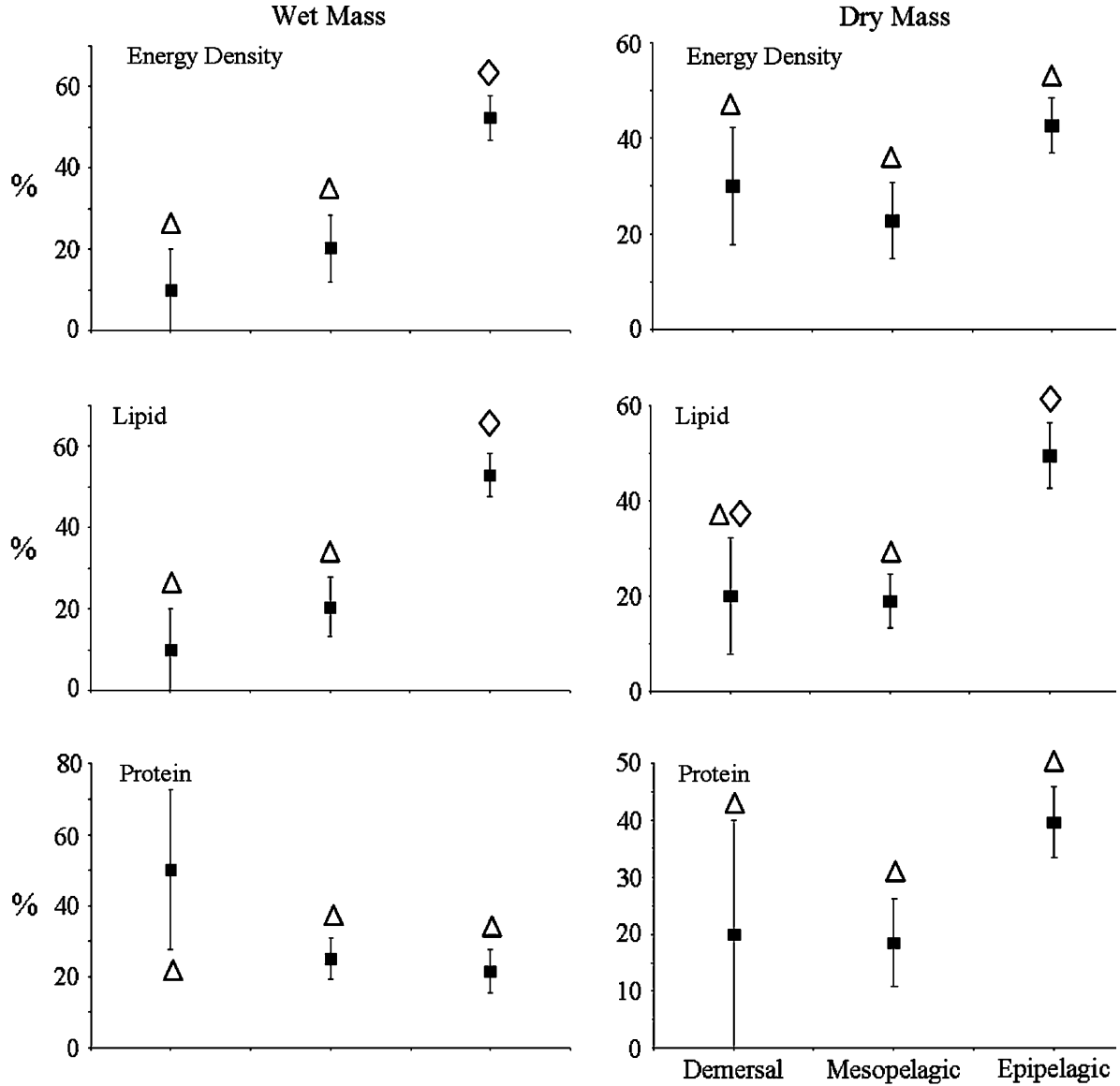

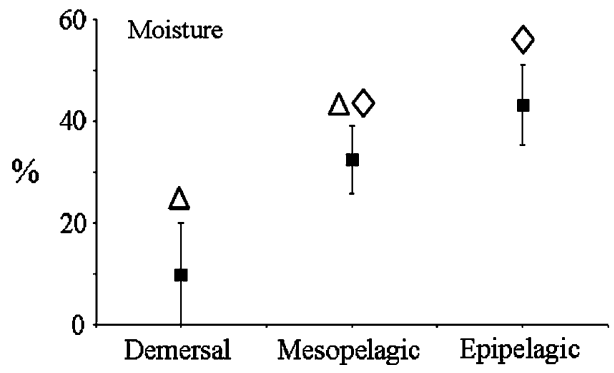


Fig. 5 Magnitude of seasonal variation in body composition of forage species depicted as the mean coefficient of variation (CV) of the annual means of body composition (energy density, lipid, protein, and moisture contents) by depth group ( $\pm \mathrm{SE})$. Like symbols indicate statistically similar groups determined by ANOVA $(P<0.05)$
Wet Mass
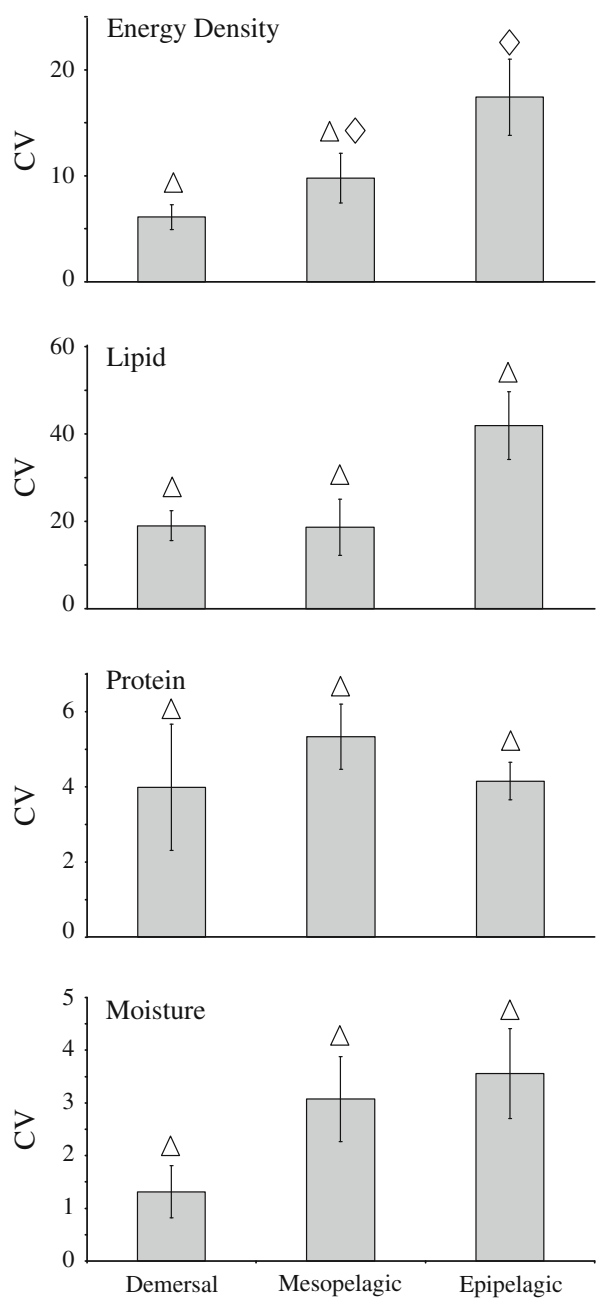

Dry Mass
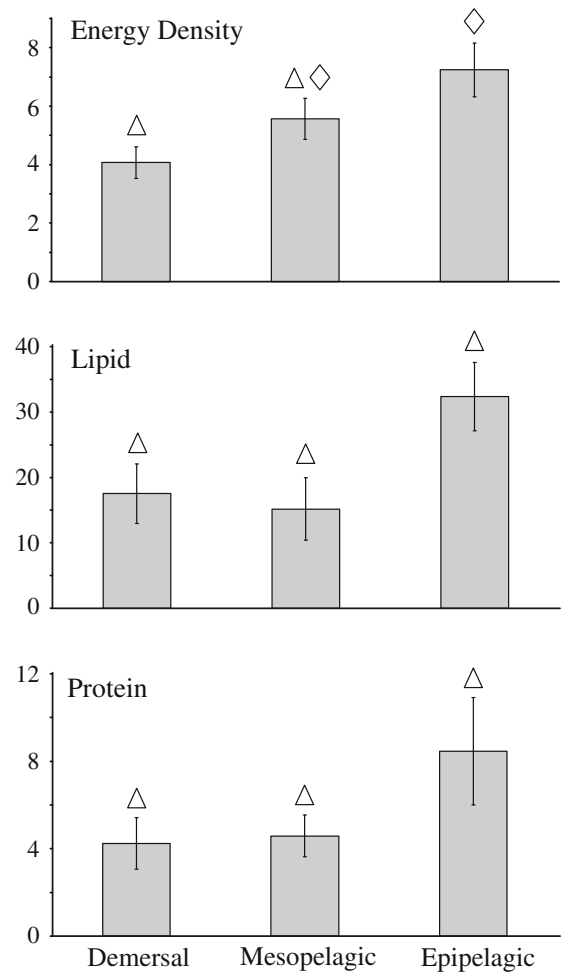

In contrast, protein content deviated from the trends observed in the other body components. The number of species in which protein content varied seasonally was relatively high in all depth strata $(83,86$, and $60 \%$, respectively, for epipelagic, mesopelagic, and demersal species). Whereas energy and lipid contents showed similar trends of decreasing seasonal variation with depth on both a wet and dry mass basis, protein content did not. On a dry mass basis, protein content adhered to the pattern of seasonal variations occurring less frequently at depth (Fig. 4). Similarly, CV's of the mean annual protein content were less variable at depth (Fig. 5). On a wet mass basis, however, the opposite trend was apparent and seasonal variations occurred more frequently in deeper-dwelling species. CV's of mean annual protein content on a wet mass basis departed from either pattern.

\section{Potential for inaccuracy}

Due to seasonal variation, annual mean estimates of body composition have limited utility. Of all the measured body components, lipid content deviated the most between annual and seasonal means. During seasons when lipid content was at a maximum or minimum, deviations from the annual mean were large $(45,21$, and $20 \%$ for epipelagic, mesopelagic, and demersal species, respectively) (ANOVA, $F(2,15)=4.00$, $P=0.041$ ) (Fig. 6). Only 4 of the 18 species examined consistently had deviations less than $10 \%$, including eulachon (Thaleichthys pacificus) (5\%), northern lampfish (Stenobrachius leucopsarus) (8\%), Northern smoothtongue (Leuroglossus schmidti) (8\%), and California headlightfish (Diaphus theta) (9\%). In contrast, 3 species incurred deviations of more than $50 \%$ during seasons of extreme lipid swings, including mature pollock (56\%), herring (59\%), and capelin (Mallotus villosus) (71\%). Because lipid is the major contributor to energy content, similar deviations in energy content between annual and seasonal means occurred. During seasons when energy content is at a maximum or minimum, deviations from the annual mean were also large (22, 11 , and $7 \%$ for epipelagic, mesopelagic, and demersal species) (ANOVA, $F(2,15)=5.39, P=0.017)$. More than half of the species examined ( 11 of the 18 species) never incurred 
Fig. 6 Maximum discrepancies $( \pm \mathrm{SE})$ in the body composition (energy density, lipid, protein, and moisture contents) between comparisons of (1) annual and seasonal mean body compositions, and (2) maximum and minimum seasonal mean body compositions. Species are grouped by depths they inhabit
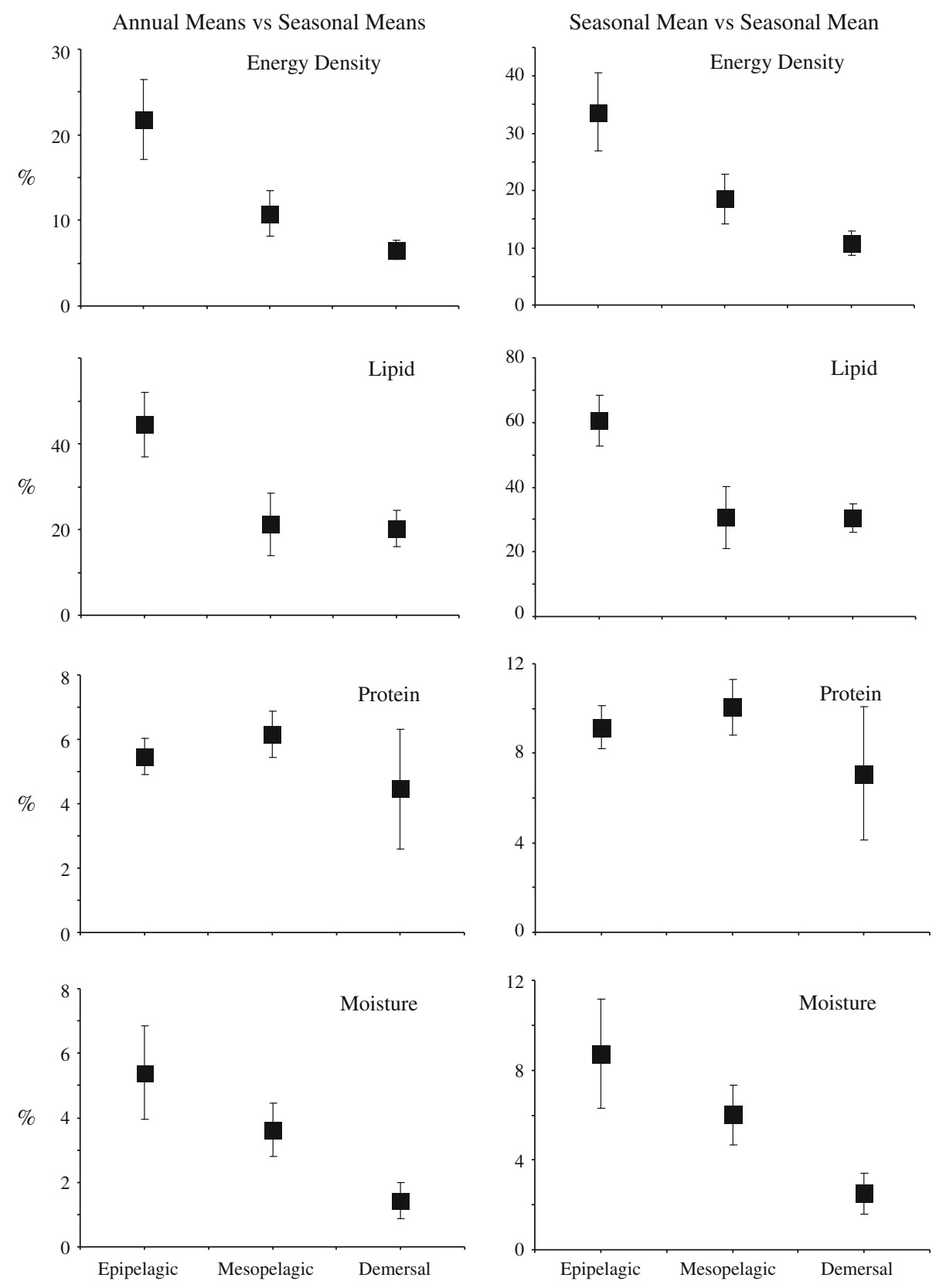

deviations greater than $10 \%$. Deviations of all other species never exceeded 35\%. Disagreements between annual and seasonal means were considerably smaller for protein and moisture contents. Deviations never exceeded $10 \%$ for either protein or moisture content, and half of the species maintained deviations less than $5 \%$ for protein content while only 4 species exceeded $5 \%$ for moisture content.

Inaccuracies incurred between seasons are even greater than those associated with annual means. With no prior knowledge of a species' seasonal variation in body composition, a researcher sampling a fish from a season of maximum lipid content and extending the value to periods of minimal lipid content could be inaccurate by as much as
$86 \%$ for epipelagic species, $72 \%$ for mesopelagic species, or $46 \%$ for demersal species (ANOVA, $F(2,15)=4.45$, $P=0.030$ ) (Fig. 6). Similarly, energy densities could be inaccurate by 56,38 , and $15 \%$ for epipelagic, mesopelagic, and demersal species, respectively (ANOVA, $F(2,15)=$ 5.02, $P=0.021)$. In contrast, protein-related discrepancies were relatively smaller, and were greater at depth $(12,15$, and $16 \%$ for epipelagic, mesopelagic, and demersal species, respectively). Moisture-related discrepancies were the smallest; however, it still exceeded $15 \%$ in epipelagic species.

Annual differences in body composition were limited to lipid and energy contents in capelin and herring in 
September. Differences in lipid content between years was 35 and $80 \%$ for herring and capelin, respectively, which drove respective differences in the energy content of 23 and $52 \%$.

Minor sources of variation in body composition

Season was the primary source of variation in forage fish body composition, while other factors had relatively minor influence. Of the 7 species that could be evaluated for annual variation (Pacific herring, capelin, eulachon, northern lampfish, commander squid, Pacific hake, and walleye pollock), only 2 showed revealed significant changes in energy and lipid contents between years, Pacific herring (ANOVA, $F(2,59)=11.95, P<0.001$ and $F(2,59)=10.09, P<0.001)$ for energy and lipid, respectively) and capelin (ANOVA, $F(1,6)=201.72$, $P<0.001$ and $F(1,6)=145.53, P<0.001$ for energy and lipid, respectively). Annual differences were all identified among September samples, which were the maximum or very near the maximum energy and lipid contents. Sampling location had little effect on the energy content of forage species, except for Pacific hake (Merluccius productus) which was lower in Frederick Sound than in Lynn Canal (4.56 and $5.62 \mathrm{~kJ} \mathrm{~g}^{-1}$, respectively; ANOVA, $F(1,100)=35.18, P<0.001)$. Within species, size effects on body composition were only moderately correlated $\left(r^{2} \leq 0.48\right)$ with the exception of chinook salmon which was highly correlated $\left(r^{2}=0.81\right)$. The chinook salmon collection included mature individuals collected in July 2003 and juveniles (length $<400 \mathrm{~mm}$ ) in the remaining collection periods. Thus, maturation was associated with increasing amounts of energy and proportions of lipid and protein in chinook salmon tissues. There were no such relationships for walleye pollock $\left(r^{2}=0.06\right)$, the only other species containing both juveniles and adults. Lastly, there was an overwhelming lack of differentiation in body composition between genders. Gender differences were only detected in two species, and these differences were not consistent between sampling periods or years. Male Pacific herring had greater protein content in March (15.46 vs. $16.60 \%$ for females and males, respectively; ANOVA, $F(1,10)=8.12, P=0.017)$ and December 2002 (15.91 vs. $16.45 \%$ for females and males, respectively; ANOVA, $F(1,29)=5.25, P=0.029)$. Male Pacific halibut had greater lipid (3.30 vs. $4.73 \%$ for females and males, respectively; ANOVA, $F(1,13)=$ 12.73, $P=0.006)$ and protein contents $(15.53$ vs. $16.53 \%$ for females and males, respectively; ANOVA, $F(1,13)=5.19, \quad P<0.000)$ and consequently energy density (4.32 vs. $5.04 \mathrm{~kJ} \mathrm{~g}^{-1}$ for females and males, respectively; ANOVA, $F(1,13)=17.86, P=0.001)$ in September 2003.

\section{Discussion}

Forage fish occupy a key trophic level transferring energy between primary or secondary producers and higher trophic levels, and thus, accurate measurements of forage fish body composition are crucial in understanding the health and energy dynamics of their mammalian, avian, and fish predators. We systematically assessed the magnitude and sources of variation in the body composition of 16 forage species from southeast Alaska. Seasonal cycles were the greatest source of variation in the body composition of forage species and were more prominent in surface-oriented species than those at depth. Significant seasonal changes were detected in the energy, lipid, and moisture content of all epipelagic species, more than half the mesopelagic species, and in only $20 \%$ of demersal species. In addition, seasonal differences in energy, lipid, and moisture contents occurred more frequently and were greater in magnitude in shallow species than in demersal species, with mesopelagic species intermediate. Protein content followed the same pattern on a dry mass basis but did not on a wet mass basis, likely due to confounding issues that arise out of wet mass comparisons. Of the species that exhibited seasonal variation, a relatively coherent seasonal cycle in body composition was observed, energy increasing with lipid during summer and autumn, peaking in late autumn or early winter, and subsequently decreasing along with protein over winter and into early spring. Though there was an effect of year on the peak energy and lipid contents in September, there was little evidence for the influence of other factors on variation in body composition, including fish length and sampling location. Thus, the factors leading to seasonal and annual variation in body composition operate over geographic scales as large as $160 \mathrm{~km}$ in water bodies characteristic of the Inside Passage in southeastern Alaska.

Implications of seasonal changes in composition with depth

Similar patterns of seasonal variation in body composition in species occupying the same depth strata indicate common life-history strategies in response to environmental conditions and energy production. Species living in shallower waters are subject to a more dynamic environment than those living in deeper water with more stable conditions. Shallow, coastal waters are influenced by atmospheric conditions, causing seasonal variation in temperature, whereas deeper waters are relatively constant (Thurman 1997). Temperature is one of the most important environmental conditions for marine organisms which vary their biological activity (metabolism, growth, etc.) under different states (Thurman 1997). Thus, declining condition 
of shallower species in winter was likely associated with decreases in energetic demands and cessation of feeding due to lower water temperatures (Wing et al. 2006; Pratt and Fox 2002; Schultz and Conover 1999).

Reductions in food availability are likely a particularly important determinant in the energy and lipid seasonality we identified. All of the epipelagic species we examined demonstrated seasonal variation in energy content driven by fluctuations in their lipid reserves. The same pattern was detected in half of the mesopelagic species examined and only 1 of the 5 demersal species, the Pacific cod. Prey resources are seasonally ephemeral in the upper water column as a result of varying photoperiods and nutrient supplies (Thurman 1997). The density of mesoplankton in Auke Bay, an embayment adjacent to the Lynn Canal sampling location, is minimized between November and February, falling to less than $10 \%$ of the value observed in June (Wing and Reid 1972). With the exception of Pacific cod, all of the seasonally influenced species we examined consume large amounts of mesoplankton (Suntsov and Brodeur 2008; Weitkamp and Sturdevant 2008; Wilson et al. 2006; Purcell and Sturdevant 2001; Yang and Nelson 2000; Sturdevant et al. 1999). Consequently, there was likely relatively little food available to these species during winter. Moreover, they apparently began storing lipid in response to decreasing food supplies in autumn, a response to resource scarcity that has been frequently described (Sogard and Olla 2000; Shuter and Post 1990; Paul and Paul 1998). This pattern of increasing energy storage as food supply declines suggests that body composition in piscivorous species should vary much less with respect to season because the abundance of their prey varies less than that of zooplanktivores. Accordingly, diets of the demersal species we examined contain large amounts of fish and non-planktivorous invertebrates (Yang and Nelson 2000). In contrast, we did not observe seasonal changes in several zooplanktivorous mesopelagic species, including California headlightfish and Northern smoothtongue. These species may have high wax content (Lea et al. 2002; Saito and Murata 1998) which could obscure seasonal changes in metabolically active lipid reserves.

Reproductive energetics also contribute significantly to the phenology of body composition. Prior to spawning, fish amass lipid depots are later utilized for the energetically expensive behaviors associated with spawning. Lipid and protein (vitellogenin) are also mobilized to provision gametes (Brett 1995; Robards et al. 1999). Of the species for which we found seasonal effects on body composition, all but Pacific sand lance and salmon are late winter or early spring spawners (Table 4). Shifts in body composition in response to spawn timing were also detected in the latter two species. Chinook salmon sampled in July were maturing and would have spawned in August. Similarly, Robards et al.
(1999) identified July as the period with peak energy content for maturing Pacific sand lance that spawn in October. Marine species at high latitudes often time spawning such that offspring can take advantage of the energy produced by spring plankton blooms (Haldorson et al. 1989). The scarcity of food in winter means that non-piscivorous spring spawners must meet the energy costs associated with gonadal recrudescence and spawning with energy acquired prior to winter. For example, Quast (1986) reported declines in the visceral fat of Pacific herring as their gonad mass increased over winter. Thus, the extreme variability in maximum energy content for spring-spawning zooplanktivores results from the need to account for the combined energetic costs of reduced feeding and reproduction.

Other factors examined for their influence on body composition were considerably less significant than season and depth effects. Annual variation was observed for several species only during peak energy and lipid contents in September prior to winter depletion. Annual variation in body composition is likely a consequence of changing habitat quality. The peak energy levels prior to winter integrate the impacts of prey production, nutritional quality, and the effects of competition into a single value. Correlations between body condition maxima and marine conditions derive from the need of zooplanktivorous fish to store energy prior to winter. Energetic minima are less variable than maxima because the minima are near the minimum energetic requirement for survival (Sogard and Olla 2000). Consequently, fish have a variety of metabolic and behavioral mechanisms to reduce the probability of dropping below these levels (Schultz and Conover 1999), thus stabilizing the lower values. In contrast, energy storage capacity should have more elasticity so that provisioning against periods of scarcity can be maximized. The energy stored during this provisioning phase is then used to fuel metabolism in the face of food scarcity and reproduction. Consequently, the amount of energy stored negatively correlates with the probability of starvation and likely influences the need to forage with its subsequent risk of predation. In addition, the amount of stored energy dictates the amount of energy that can ultimately be invested in reproduction.

A spatial component to variation in energy and lipid contents appears to be insignificant on the scale examined here $(160 \mathrm{~km})$. Spatial differences in the body composition of mature fish have been found on much larger scales than we examined here, likely due to a lag in bloom times associated with latitudinal differences as well as localized diets. For example, body composition of walleye pollock in the Bering Sea and southeastern Alaska has been shown to be different (Schaufler et al. 2005) as well as other species compared between the Bering Sea and Gulf of Alaska (Perez 1994). Lastly, the effect of fish size had only a slight bearing on body composition, likely because juveniles were not encountered 
Table 4 Spawn timing of forage species in southeastern Alaska

\begin{tabular}{|c|c|c|c|}
\hline & Spawn timing & Location & Source \\
\hline \multicolumn{4}{|l|}{ Epipelagic } \\
\hline Capelin & $\begin{array}{l}\text { April }{ }^{1} \text {, peak in June-July, } \\
\text { 2nd spawn in autumn }{ }^{2}\end{array}$ & Gulf of AK & $\begin{array}{l}\text { Observation during study } \\
\text { Doyle et al. }(2002)^{2}\end{array}$ \\
\hline Chinook salmon & May-July & Cook Inlet, AK & Healey (1991) \\
\hline Pacific herring & Late April, early May & Southeast AK & Carlson (1985) \\
\hline Pacific sand lance & October & & Robards et al. (1999) \\
\hline \multicolumn{4}{|l|}{ Mesopelagic } \\
\hline California headlightfish & Peak in May-July, ranges March-September & Japan & Moku et al. (2003) \\
\hline Commander squid & December-May, peak February-March & SW Japan & Yuuki and Kitazawa (1986) \\
\hline Eulachon & April & Southeast AK & Sigler et al. (2004) \\
\hline Northern lampfish & Larval fish in January & California & Icanberry et al. (1978) \\
\hline Northern smoothtongue & Larval fish observed in May-June & Prince William Sound AK & Norcross and Frandsen (1996) \\
\hline Pacific hake & March-May & Strait of Georgia & McFarlane and Beamish (1986) \\
\hline Walleye pollock & $\begin{array}{l}\text { Peak March-May, } \\
\text { extended over 4-5 months }\end{array}$ & Southeast AK & Haldorson et al. (1989) \\
\hline \multicolumn{4}{|l|}{ Demersal } \\
\hline Arrowtooth flounder & September-February & Bering Sea, Washington & Rickey (1995) \\
\hline Pacific cod & January $^{1}$, winter ${ }^{2}$ & Bering Sea, Yakutat & $\begin{array}{l}\text { Klovach et al. }(1995)^{1} ; \\
\text { Rogers et al. }(1981)^{2}\end{array}$ \\
\hline Pacific halibut & December-January & Gulf of AK & St-Pierre (1984) \\
\hline Sablefish & February-May & Gulf of $\mathrm{AK}^{1}, \mathrm{Canada}^{2}$ & Mason et al. (1983) \\
\hline Sandpaper skate & Unknown & & \\
\hline
\end{tabular}

$A K$ Alaska, $P W S$ Prince William Sound, SW Southwest

for many of the species examined. This is consistent with other studies in which body composition frequently did not correlate with fish size (Anthony et al. 2000; Lawson et al. 1998). The effect of size is more thoroughly examined for walleye pollock in Heintz and Vollenweider (in press).

\section{Sampling implications}

Directed sampling efforts are critical to assess the biochemical composition of forage species in order to avoid potential inaccuracies caused primarily by season and secondarily by year effects. We found variable body composition in more than $80 \%$ of the forage species we examined. Spring-spawning, pelagic zooplanktivores had the most labile body composition, while benthic piscivores were more consistent, as were a myctophid and bathylagid that may buffer their lipid content with waxes. Seasonal differences were primarily associated with peak lipid and energy stores integrated over summer and energetic minima in the subsequent spring resulting from winter starvation and reproductive expenditures. Despite decreasing variability with depth (except for protein that increased with depth), the potential for seasonally related inaccuracies in body composition was always great $(>10 \%)$ with one exception. The only component of body composition that was never inaccurate by more than $5 \%$ is the moisture content of demersal species. Annual differences in body composition frequently corresponded to peak energy stores resulting from differences in summer productivity. If unaccounted for, these factors may introduce significant inaccuracies in the estimates of body composition.

Energetic modeling implications

Inaccurate estimates of forage fish body composition have significant implications for bioenergetic models, which are highly sensitive to fish condition inputs (Shelton et al. 1997). For example, using Winship et al.'s (2002) estimates of Steller sea lion energy requirements, predation rates vary by a factor of 2.5 when comparing diets consisting solely of the fattest herring collected prior to winter versus the leanest herring collected in spring. Use of non-representative body composition values also has implications for the exploitation rates of forage fish populations. Extrapolating the contrasting predation rates over the 2000 Steller sea lions occupying haul-outs adjacent to our study sites (Womble et al. 2008), there is a discrepancy of 9,000 metric tons of herring consumed, which is approximately $1 / 3$ of the peak herring biomass at the study sites (Sigler et al. 2009; Sigler and Csepp 2007). Thus, researchers must be cognizant of using body composition estimates appropriate to their study design, with particular attention paid to season. 
Summary

Body composition analyses are a rich source of information regarding population fitness, habitat quality, and trophic relations that can be of direct value to ecosystem managers. The relationship between seasonal variation in body composition and depth we describe illustrates that trade-offs between growth and storage are ubiquitous features of the life history of marine zooplanktivores. Several authors have exploited these trade-offs to understand the sizedependent mortality in juvenile fish (Schultz and Conover 1999). These data reveal the existence of similar trade-offs between growth and storage in adult zooplanktivores and may be useful for resolving the relationship between spawning stock biomass and recruitment (Marshall et al. 2000). Finally, estimates of body composition are integral to understanding the energy sources consumed by predators and therefore provide a biologically meaningful way of evaluating diet composition. Managers increasingly require tools that integrate ecosystem processes in simple but meaningful ways. Monitoring the body composition of forage fish species offers managers such a tool. These measures neatly integrate annual changes in the amount of energy derived from annual production cycles, while simultaneously measuring the amount of energy that can be invested into the subsequent generation.

Acknowledgments We gratefully acknowledge M. Sigler of Auke Bay Laboratories (ABL), who was the principal investigator of a collaborative study which provided the logistical support and the vessel from which our samples were collected. This project would not have been possible without his key participation. Also from ABL, F. Sewall, W. Fournier, and D. Greenwell contributed significantly to chemical analyses and laboratory processing of samples. In addition, D. Csepp (ABL) organized hydro-acoustics and provided logistical support. A portion of the data included in this study were collected and analyzed for J.J.V.'s masters thesis at the University of Alaska, Fairbanks (UAF), School of Fisheries and Ocean Sciences. B. Kelly, M. Stekoll, and M. Adkison from UAF were members of J.J.V's masters thesis committee and instrumental reviewers. Financial support was provided by the National Oceanographic and Atmospheric Administration's Steller sea lion funds. Additional funding was provided to J.J.V. by the University of Alaska Sea Grant.

Open Access This article is distributed under the terms of the Creative Commons Attribution Noncommercial License which permits any noncommercial use, distribution, and reproduction in any medium, provided the original author(s) and source are credited.

\section{References}

Anthony JA, Roby DD, Turco KR (2000) Lipid content and energy density of forage fishes from the northern Gulf of Alaska. J Exp Mar Biol Ecol 248:53-78

Bando MKH (2002) Comparing the nutritional quality of Steller sea lion (Eumetopias jubatus) diets. Master thesis, University of Alaska, Fairbanks, AK
Bradford-Grieve JM, Probert PK, Nodder SD, Thompson D, Hall J, Hanchet S, Boyd P, Zeldis J, Baker AN, Best HA, Broekhuizen N, Childerhouse S, Clark M, Hadfield M, Safi K, Wilkinson I (2003) Pilot trophic model for subantarctic water over the Southern Plateau, New Zealand: a low biomass, high transfer efficiency system. J Exp Mar Biol Ecol 289(2):223-262

Brett JR (1995) Chapter 1: energetics. In: Groot C, Margolis L, Clarke WC (eds) Physiological Ecology of Pacific Salmon. UBC Press, Vancouver

Carlson HR (1985) Seasonal distribution and environment of adult pacific herring (Clupea harengus pallasi) near Auke Bay, Lynn Canal, southeastern Alaska. Dissertation, Oregon State University, Corvallis, WA

Christie WW (2003) Lipid analysis: isolation, separation, identification, and structural analysis of lipids, 3rd edn. Oily Press, Bridgwater

Ciannelli L, Paul AJ, Brodeur RD (2002) Regional, interannual and size-related variation of age 0 year walleye pollock whole body energy content around the Pribilof Islands, Bering Sea. J Fish Biol 60:1267-1279

Craig JF, Kenley MJ, Talling JF (1978) Comparative estimations of the energy content of fish tissue from bomb calorimetry, wet oxidation and proximate analysis. Freshw Biol 8:585-590

Deangelis DL, Shuter BJ, Ridgway MS, Scheffer M (1993) Modeling growth and survival in an age-0 fish cohort. Trans Am Fish Soc 122:927-941

Doyle MJ, Busby MS, Duffy-Anderson JT, Picquelle SJ, Matarese AC (2002) Aspects of the early life history of capelin (Mallotus villosus) in the Northwest Gulf of Alaska: a historical perspective based on larval collections October 1977-March 1979. NOAA Tech Mem NMFS AFSC 132

Foy RJ, Norcross BL (1999) Spatial and temporal variability in the diet of juvenile Pacific herring (Clupea pallasii) in Prince William Sound, Alaska. Can J Zool 77(5):697-706

Foy RJ, Paul AJ (1999) Winter feeding and changes in somatic energy content of age-0 Pacific herring in Prince William Sound, Alaska. Trans Am Fish Soc 128:1193-1200

Haldorson L, Watts J, Sterritt D, Pritchett M (1989) Seasonal abundance of larval walleye pollock in Auke Bay, Alaska, relative to physical factors, primary production, and production of zooplankton prey. Proc. Int Symp Biol Mgmt Walleye Pollock. University of Alaska. Alaska Sea Grant, Fairbanks, pp 159-172

Healey MC (1991) Life history of Chinook salmon (Oncorhynchus tshawytscha). In: Groot C, Margolis L, Clarke WC (eds) Pacific salmon life histories. UBC Press, Vancouver, pp 313-393

Heintz RA, Vollenweider JJ. Influence of size on the sources of energy consumed by overwintering walleye pollock (Theragra chalcogramma). J Exp Mar Bio Ecol (in press)

Icanberry JW, Warrick JW, Rice DW (1978) Seasonal larval fish abundance in waters off Diablo Canyon, California. Trans Am Fish Soc 107(2):225-233

Iverson SJ, Frost KJ, Lang SLC (2002) Fat content and fatty acid composition of forage fish and invertebrates in Prince William Sound, Alaska: factors contributing to among and within species variability. Mar Ecol Prog Ser 241:161-181

Jenkins AR, Keeley ER (2010) Bioenergetic assessment of habitat quality for stream-dwelling cutthroat trout (Oncorhynchus clarkia bouvieri) with implications for climate change and nutrient supplementation. Can J Fish Aquat Sci 67:371-385

Kitts DD, Huynhl MD, Hu C, Trites AW (2004) Seasonal variation in nutrient composition of Alaskan walleye pollock. Can J Zool 82:1408-1415

Klovach NV, Rovnina OA, Kol'tsov DV (1995) Biology and exploitation of Pacific cod, Gadus macrocephalus, in the Anadyr-Navarin region of the Bering Sea. J Ichthyol 35:48-52 
Lawson JW, Magalhaes AM, Miller EH (1998) Important prey species of marine vertebrate predators in the northwest Atlantic: proximate composition and energy density. Mar Ecol Prog Ser 164:13-20

Lea MA, Cherel Y, Guinet C, Nichols PD (2002) Antarctic fur seals foraging in the polar frontal zone: inter-annual shifts in diet as shown from fecal and fatty acid analyses. Mar Ecol Prog Ser 245:281-297

Leaper R, Lavigne D (2007) How much do large whales eat? J Cetacean Res Manage 9(3):179-188

Marshall CT, Yaragina NA, Aadlandsvik B, Dolgov AV (2000) Reconstructing the stock-recruitment relationship for northeast Artic cod using a bioenergetic index of reproductive potential. Can J Fish Aquat Sci 57(12):2433-2442

Mason JC, Beamish RJ, McFarlane GA (1983) Sexual maturity, fecundity, spawning, and early life history of sablefish (Anoplopoma fimbria) off the Pacific coast of Canada. Can J Fish Aquat Sci 40(12):2126-2134

McFarlane GA, Beamish RJ (1986) Biology and fishery of Pacific hake (Merluccius productus) in the Strait of Georgia. Mar Fish Rev 47(2):23-34

Moku M, Tsuda A, Kawaguchi K (2003) Spawning season and migration of the myctophid fish Diaphus theta in the western North Pacific. Ichthyol Res 50(1):52-58

Montevecchi WA, Piatt J (1984) Composition and energy contents of mature inshore spawning capelin (Mallotus villosus): implications for seabird predators. Comp Biochem Physiol 78A:15-20

Morissette L, Kaschner K, Gerber LR (2010) Ecosystem models clarify the trophic role of whales off Northwest Africa. Mar Ecol Prog Ser 404:289-302

Moss JH, Farley EV, Feldman AM, Ianelli JN (2009) Spatial distribution, energetic status, and food habits of eastern Bering Sea age-0 walleye pollock. Trans Am Fish Soc 138:497-505

Norcross BL, Frandsen M (1996) Distribution and abundance of larval fishes in Prince William Sound, Alaska, during 1989 after the Exxon Valdez oil spill. In: Rice SD, Spies RB, Wolfe DA, Wright BA (eds) Exxon Valdez Oil Spill Symp, Anchorage AK, 2-5 Feb 1993, pp 463-486

Paul AJ, Paul JM (1998) Spring and summer whole-body energy content of Alaskan juvenile Pacific herring. AK Fish Res Bull 5:131-136

Paul AJ, Paul JM, Brown ED (1996) Ovarian energy content of Pacific herring from Prince William Sound, Alaska. Alaska Fish Res Bull 3(2):103-111

Paul AJ, Paul JM, Brown ED (1998) Fall and spring somatic energy content for Alaskan Pacific herring (Clupea pallasi Valenciennes 1847) relative to age, size and sex. J Exp Mar Biol Ecol 223:133-142

Payne SA, Johnson AB, Otto RS (1999) Proximate composition of some north-eastern Pacific forage fish species. Fish Oceanogr 8:159-177

Perez MA (1994) Calorimetry measurements of energy value of some Alaskan fishes and squids. NOAA Technical Memo 1-18. NMFS, NOAA, US Dept Commerce

Pratt TC, Fox MG (2002) Influence of predation risk on the overwinter mortality and energetic relationships of young-ofyear walleyes. Trans Am Fish Soc 131(5):885-898

Purcell JE, Sturdevant MV (2001) Prey selection and dietary overlap among zooplanktivorous jellyfish and juvenile fishes in Prince William Sound, Alaska. Mar Ecol Prog Ser 210:67-83

Quast JC (1986) Annual production of eviscerated body weight, fat, and gonads by Pacific herring, Clupea harengus pallasii, near Auke Bay, southeastern Alaska. Fish Bull 84(3):705-721

Rickey MH (1995) Maturity, spawning, and seasonal movement of arrowtooth flounder, Atheresthes stomias, off Washington. Fish Bull 93(1):127-138
Robards MD, Anthony JA, Rose GA, Piatt JF (1999) Changes in proximate composition and somatic energy content for Pacific sand lance (Ammodytes hexapterus) from Kachemak Bay, Alaska relative to maturity and season. J Exp Mar Biol Ecol 241:245-258

Robbins CT (1993) Wildlife feeding and nutrition. Academic Press Inc, San Diego, CA

Rogers BJ, Wangerin ME, Garrison KJ, Rogers DE (1981) Epipelagic meroplankton, juvenile fish, and forage fish: distribution and relative abundance in coastal waters near Yakutat. NOAA OMPA, Boulder

Saito H, Murata M (1998) Origin of the monoene fats in the lipid of midwater fishes: relationship between the lipids of myctophids and those of their prey. Mar Ecol Prog Ser 168:21-33

Schaufler L, Logerwell E, Vollenweider JJ (2005) Variation in the quality of Steller sea lion prey from the Aleutian Islands and southeastern Alaska. In: Trites AW, Atkinson SK, DeMaster DP, Fritz LW, Gelatt TS, Rea LD, Wynne KM (eds) 22nd Wakefield Fisheries Symposium: Sea Lions of the World. Anchorage, Alaska, pp 117-129

Schultz ET, Conover DO (1997) Latitudinal differences in somatic energy storage: adaptive responses to seasonality in an estuarine fish (Atherinidae: Medidia menidia). Oecologia 109:516-529

Schultz ET, Conover DO (1999) The allometry of energy reserve depletion: test of a mechanism for size-dependent winter mortality. Oecologia 119(4):474-483

Shelton PA, Warren WG, Stenson GB (1997) Quantifying some of the major sources of uncertainty associated with estimates of harp seal prey consumption. Part 2: uncertainty in consumption estimates associated with population size, residency, energy requirement and diet. J Northwest Atl Fish Sci 22:303-315

Shulman GE, Nikolsky VN, Yuneva TV, Minyuk GS, Shchepkin VY, Shchepkina AM, Ivleva EV, Yunev OA, Dobrovolov IS, Bingel F, Kideys AE (2005) Fat content in Black Sea sprat as an indicator of fish food supply and ecosystem condition. Mar Ecol Prog Ser 293:201-212

Shuter BJ, Post JR (1990) Climate, population viability, and the zoogeography of temperate fishes. Trans Am Fish Soc. Proceedings from the symposium on effects of climate change on fish, Toronto, Ontario, Canada, 14-15 Sept 1988

Sidwell VD (1981) Chemical and nutritional composition of finfishes, whales, crustaceans, mollusks, and their products. NOAA Tech Memo. NMFS, NOAA, US Dept Commerce

Sigler MF, Csepp DJ (2007) Seasonal abundance of two important forage species in the North Pacific Ocean, Pacific herring and walleye pollock. Fish Res 83:319-331

Sigler MF, Womble JN, Vollenweider JJ (2004) Availability to Steller sea lions (Eumetopias jubatus) of a seasonal prey resource: a prespawning aggregation of eulachon (Thaleichthys pacificus). Can J Fish Aquat Sci 61(8):1475-1484

Sigler MF, Tollit DJ, Vollenweider JJ, Thedinga JF, Csepp DJ, Womble JN, Wong MA, Rehberg MJ, Trites AW (2009) Steller sea lion foraging response to seasonal changes in prey availability. Mar Ecol Prog Ser 388:243-261

Sogard SM, Olla BL (2000) Endurance of simulated winter conditions by age- 0 walleye pollock: effects of body size, water temperature and energy stores. J Fish Biol 56(1):1-21

St-Pierre G (1984) Spawning locations and season for Pacific halibut. Sci Rep IPHC 70

Sturdevant MV, Willette TM, Jewett SC, Debevec E, Hulbert LB, Brase ALJ (1999) Forage fish diet overlap, 1994-1996. Exxon Valdez Oil Spill Trustee Council, Restoration Project Final Report 97163C, pp 108

Suntsov AV, Brodeur RD (2008) Trophic ecology of three dominant myctophid species in the northern California Current region. Mar Ecol Prog Ser 373:81-96 
Sweeney R, Rexroad P (1987) Comparison of LECO FP-528 nitrogen determination with AOAC copper catalyst Kjeldahl method for crude protein. J AOAC 70:1028-1030

Thurman HV (1997) Introduction to Oceanography. Prentice Hall, Upper Saddle River

Van Pelt TI, Piatt JF, Lance BK, Roby DD (1997) Proximate composition and energy density of some north Pacific forage fishes. Comp Biochem Physiol 118A:1393-1398

Vollenweider JJ (2005) Variability in Steller sea lion (Eumetopias jubatus) prey quality in southeastern Alaska. Master thesis, University of Alaska, Fairbanks, AK

Watt BK, Merrill AL (1963) Composition of foods: raw, processed, prepared. Agricultural Handbook 8. US Dept Agr, Washington, DC

Weitkamp LA, Sturdevant MV (2008) Food habits and marine survival of juvenile Chinook and coho salmon from marine waters of Southeast Alaska. Fish Oceanogr 17(5):380-395

Wilson MT, Jump CM, Duffy-Anderson JT (2006) Comparative analysis of the feeding ecology of two pelagic forage fishes: capelin Mallotus villosus and walleye pollock Theragra chalcogramma. Mar Ecol Prog Ser 317:245-258

Wing BL, Reid GM (1972) Surface zooplankton from Auke Bay and vicinity, southeastern Alaska, August 1962 to January 1964. Data Rep. Natl. Oceanic Atmos Adm, Seattle. no 72

Wing BL, Masuda MM, Taylor SG (2006) Time series analyses of physical environmental data records from Auke Bay, Alaska. NOAA Technical Memo NMFS-AFSC-166
Winship AJ, Trites AW, Rosen DAS (2002) A bioenergetic model for estimating the food requirements of Steller sea lions Eumetopias jubatus in Alaska, USA. Mar Ecol Prog Ser 229:291-312

Witteveen BH, Foy RH, Wynne KM (2006) The effect of predation (current and historical) by humpback whales (Megaptera novaeangliae) on fish abundance near Kodiak Island, Alaska. Fish Bull 104(1):10-20

Womble JN, Sigler MF (2006a) Seasonal availability of abundant, energy-rich prey influences the abundance and diet of a marine predator, the Steller sea lion Eumetopias jubatus. Mar Ecol Prog Ser 325:281-293

Womble JN, Sigler MF (2006b) Temporal variation in Steller sea lion diet at a seasonal haul-out in southeast Alaska. In: Trites AW, Atkinson SK, DeMaster DP, Fritz LW, Gelatt TS, Rea LD, Wynne KM (eds) 22nd Wakefield Fisheries Symposium: Sea Lions of the World. Anchorage, Alaska, pp 141-154

Womble JN, Sigler MF, Willson MF (2008) Linking seasonal distribution patterns with prey availability in a central-place forager, the Steller sea lion. J Biogeogr 36(3):439-451

Yang MS, Nelson MW (2000) Food habits of the commercially important groundfishes in the Gulf of Alaska in 1990, 1993, and 1996. NOAA Tech Memo NMFS-AFSC-112. NMFS, NOAA, US Dept Commerce

Yuuki Y, Kitazawa H (1986) Berryteuthis magister in the southwestern Japan Sea. Bull Jap Soc Sci Fish 52(4):665-672 